\title{
Early psychomotor development of children from triple pregnancy - case study
}

\begin{abstract}
The aim of this study was to analyze the specificity and dynamics of psychomotor development in children from triplet pregnancy.

The studied group was composed of siblings from triple pregnancy $(\mathrm{T} 1, \mathrm{~T} 2, \mathrm{~T} 3)$, including two girls and one boy. This longitudinal study comprised three stages: stage I - children aged 25 months, stage II - children aged 29 months, and stage III - children aged 38 months. At each stage, the psychomotor development of children was examined with the Third Edition of Bayley Scales of Infant and Toddler Development (BSID-III) and subjectively by their mother. Additionally, medical and nursing documentation was analyzed.
\end{abstract}

\begin{abstract}
Individual psychomotor development of children from triple pregnancy is different with regards to various spheres, and has different rates and dynamics throughout consecutive years.

Psychomotor development of children from triple pregnancies is determined by gender and postnatal clinical parameters, i.e. birth weight, head circumference, postnatal morbidity, and prematurity-related conditions.
\end{abstract}

\section{KEY WORDS}

premature aging; pregnancy multiple; postnatal development; psychomotor disorders

organizations - 1: GAMUT, Uni Research Health, Bergen, Norway · 2: Institute of Psychology, University of Gdansk, Gdansk, Poland · 3: Kindergarten No. 77 for Children with Cerebral Palsy, Gdansk, Poland

AUthors' CONTRIBution - A: Study design - B: Data collection - C: Statistical analysis - D: Data interpretation .

E: Manuscript preparation - F: Literature search - G: Funds collection

CORRESPONDING AUTHOR - Prof. Mariola Bidzan, Institute of Psychology, University of Gdansk, 4 Bażyńskiego Str., 80-952 Gdansk, Poland, e-mail: mariola.bidzan@ug.edu.pl

to Cite this ARTICLE - Bieleninik, Ł., Bidzan, M., \& Koszewska, A. (2015). Early psychomotor development of children

from triple pregnancy - case study. Health Psychology Report, 3(1), 85-97. DOI: 10.5114/hpr.2015.44936

RECEIVED 25.04.2014 · REVIEWED 16.05.2014 · ACCEPTED 23.05.2014 · PUBLISHED 29.08.2014 


\section{BACKGROUND}

The prevalence of triplet pregnancies is estimated at about $0.70 \%$ of all pregnancies; however, their number is constantly increasing. It is estimated that compared to 1980, the fraction of triplets increased by $454 \%$ (Kornacka \& Sonczyk, 2008). In 1990, there were 153 triplet pregnancies in Poland; the number increased to 225 in 2006, 321 in 2007, 305 in 2009, and 307 in 2010 (Central Statistical Office of Poland).

Łucja Bieleninik, Mariola Bidzan, Aneta Koszewska status (Nowakowska \& Wilczyński, 2003; Kempiak,
Triplet pregnancy is associated with a high risk of perinatal mortality, prematurity, and poor neonatal 2003). The studies conducted in Poland revealed that the intrauterine death and perinatal mortality rates in triplet pregnancies are $23.40 \%$ and $27.40 \%$, respectively. Compared to the 1970 s, the fraction of live born neonates from triplet pregnancies has increased by $700 \%$ (Malinowski, 2009). Triplet pregnancy is associated with a high risk of preterm birth, which is ten-fold higher than in singleton pregnancy (Nowakowska \& Wilczyński, 2003). Although preterm birth rates of triplet pregnancies are country specific, they vary between about 75\% (Gadzinowski \& Gulczyńska, 2003) and about 94\% (Pietrzycka \& Gadzinowski, 2007). According to Pawelczyk and Derwich (2003), preterm births occur in $100 \%$ of triplet pregnancies (including $22.20 \%$ of pregnancies terminated before the $32^{\text {nd }}$ week of gestation, $51 \%$ of pregnancies ending before the $34^{\text {th }}$ week, and $64 \%$ of pregnancies completed before the $35^{\text {th }}$ week). It should be mentioned that factors determining the survival of preterm neonates from multiple pregnancies include the frequency and type of pregnancy complications, type of multiple pregnancy, history of multiple pregnancies, history of preterm births, low birth weight, uneven growth of fetuses, gender, mode of pregnancy termination, maternal comorbidities, and maternal race (Kempiak, 2003). Chorionicity should also be considered in the case of a multiple pregnancy as monochorionic pregnancies are generally associated with higher morbidity rates (Kornacka, 2003b; Kempiak, 2003; Szymankiewicz, 2010). The perinatal mortality rate for dichorionic pregnancy is $4.80 \%$, as compared to $9.60 \%$ for monochorionic diamniotic pregnancy, and $29 \%$ for monochorionic monoamniotic pregnancy (Malinowski \& Bręborowicz, 2010). Moreover, the perinatal mortality rate is also determined by zygosity, ranging between $28 \%$ and $47 \%$ for monozygotic twins, and from $6 \%$ to $20 \%$ for dizygotic twins (Kornacka, 2003b). Finally, the mortality rate is higher for the second twin from the pair (Kempiak, 2003).

Termination of multiple pregnancy results in the delivery of preterm neonates, constituting a particular risk group due to the immaturity of their vital systems (Kostuch, 2009), including thermoregulatory, respiratory (e.g. respiratory distress syndrome
- RDS, bronchopulmonary dysplasia - BPD, apnea, congenital pneumonia), alimentary (e.g. necrotizing enterocolitis - NEC), circulatory (e.g. patent ductus arteriosus - PDA), nervous (e.g. ischemia, hypoxia, periventricular leukomalacia - PVL, periventricular/ intraventricular hemorrhage - PVH/IVH), hematopoietic, urinary, skeletal, and immune system, as well as the organs of vision (retinopathy of prematurity - ROP) and hearing (Bieleninik, 2012). Also, a higher incidence of neurodevelopmental disorders should be considered in this group (e.g. Woodward, Anderson, Austin, Howard, \& Inder, 2006; Kania, 2008), particularly in neonates with extremely low birth weight (Bracewell \& Marlow, 2002; Kornacka, 2003b; Woodward et al., 2006). Signs of neurological disorders, and particularly signs of cerebral palsy (van Kessel-Feddema, Sondaar, de Kleine, Verhaak, \& van Baar, 2007), are observed in approximately $50 \%$ of preterm neonates (Kornacka, 2003b). The prevalence of cerebral palsy in children from multiple pregnancies can be even 12 times higher than in neonates from singleton pregnancies (Kornacka, 2003b). The abovementioned data suggest that preterm neonates represent a unique group of children, which requires a multidisciplinary approach (neonatology, logopedic, psychological care, and rehabilitation) beginning in the first days of their lives (Bieleninik, 2012). Early intervention is very important due to provides a better chance for survival as well as offers the compensation of development opportunities (Bieleninik \& Gold, 2014). Review by Bieleninik \& Gold (2014) has shown that much research has significant positive effects of NICU's early intervention (including: Kangaroo Care, Newborn Individualized Developmental Care and Assessment Program, and Music Therapy) on mortality, medical health and bond between parents and premature infants in the first year of life. It is necessary to mention about the new polish study by Chrzan-Dętkoś, Pawlicka, and Bogdanowicz (2014). The Authors have indicated that kangaroo mother care has a protective impact both on health and future cognitive skills of prematurely born babies.

High-risk children not only require specialist care at the intensive care unit, but also specialist follow-up lasting at least up to the third year of age (Stoińska \& Montgomery, 2003), and sometimes even up to eight years of age (Kornacka, 2003a). Developmental support of preterm children represents one of the challenges of modern developmental, clinical, and rehabilitation-related psychology.

The aim of this study was to analyze the specificity and dynamics of psychomotor development in children from triplet pregnancy. Moreover, we investigated for any relationships between the development and health consequences of triple pregnancy, prematurity, and the overall health status. 
Table 1

Perinatal indices of examined group $(T 1, T 2, T 3)$

\begin{tabular}{lccc}
\hline Variable & $\mathrm{T}^{*}$ & $\mathrm{~T} 2^{*}$ & $\mathrm{~T}^{*}$ \\
\hline Gender & $\mathrm{F}$ & $\mathrm{M}$ & $\mathrm{F}$ \\
Gestational age (weeks) & 29 & 29 & 29 \\
Mode of delivery & Cesarean section & Cesarean section & Cesarean section \\
Zygosity & $\mathrm{MZ}$ & $\mathrm{DZ}$ & $\mathrm{MZ}$ \\
Sequence of delivery & $\mathrm{I}$ & $\mathrm{III}$ & $\mathrm{II}$ \\
Presentation & Head & Transverse & Breech \\
Birth weight (g) & 980 & 1240 & 720 \\
Body length at birth & 38 & 43 & 36 \\
Head circumference & 29 & 29 & 25 \\
Chest circumference & 25 & 27 & 7 \\
Apgar score at 1' & 7 & 5 & 7 \\
Apgar score at 5 & 7 & 7 & 7 \\
\hline
\end{tabular}

Note. *This designation will be used throughout the following text

\section{PARTICIPANTS AND PROCEDURE}

\section{METHODS}

This longitudinal study comprised three stages: stage I - children aged 25 months, stage II - children aged 29 months, and stage III - children aged 38 months. At each stage, the psychomotor development of children was examined with the Third Edition of Bayley Scales of Infant and Toddler Development (BSID-III); moreover, the psychomotor development of the children was evaluated subjectively by their mother. Additionally, medical and nursing documentation was analyzed at stage I, and an interview was obtained. Generally, the development of preterm neonates is analyzed with regards to the corrected age; however, the psychomotor development of our children was analyzed after completing 24 months of age, and therefore we did not use correction for age along with the BSID-III protocol.

\section{STUDIED GROUP}

The studied group was composed of siblings from triple pregnancy (T1, T2, T3), including two girls and one boy. The children were born on January $15^{\text {th }}, 2009$ at a hospital in Gdansk (Northern Poland). Parents possessed post-secondary education, the pregnancy was planned, and the father was present at birth. The mother assessed the economic status of the family as moderate. The pregnancy was qualified as a high-risk pregnancy, and the mother was on sick leave throughout this period. Noticeably, she was hospitalized due to bleeding after gestational week 28, oligohydramnios, and hypertrophy of one fetus (T1).

\section{ANALYSIS OF MEDICAL AND NURSING DOCUMENTATION}

During the analysis of medical and nursing documentation, the perinatal characteristics of the triples (T1, T2, T3) were obtained; they are summarized in Table 1.

The children were born with signs of hypoxia and required oxygen administration, artificial ventilation, and intubation. All children achieved the same Apgar scores at 5 minutes: 2 points for cardiac and respiratory function, and 1 point for reflexes, muscular tone, and coloration of the skin. They were all diagnosed with infant respiratory distress syndrome, infection, retinopathy of prematurity, anemia, hyperbilirubinemia, and hyperglycemia. Additionally, T2 suffered from periventricular leukomalacia, T1 had patent ductus arteriosus, and T1 and T3 were diagnosed with intraventricular hemorrhage. T3 had chronic lung disease, and ventriculoperitoneal shunting at the age of 12 months.

\section{MEDICAL AND PSYCHOLOGICAL DIAGNOSIS}

Beginning in February 2011, the children took part in the classes of early developmental support offered by a specialist kindergarten for children with cerebral palsy, and started the classes of early support in October 2011. Moreover, they all participated in four two-week cycles of rehabilitation; additionally, T2 and T3 completed one more course of rehabili-
Triple pregnancy - psychomotor development 
Table 2

Present medical and psychological status of examined siblings of triple pregnancy (T1, T2, T3)

\begin{tabular}{|c|c|c|c|}
\hline & $\mathrm{T} 1$ & $\mathrm{~T} 2$ & T3 \\
\hline $\begin{array}{l}\text { Medical } \\
\text { diagnosis }\end{array}$ & \multicolumn{2}{|c|}{$\begin{array}{c}\text { Preterm neonate from triple pregnancy } \\
\text { (gestational week 29) }\end{array}$} & $\begin{array}{l}\text { Preterm neonate from triple } \\
\text { pregnancy (gestational week 29), } \\
\text { bronchopulmonary dysplasia }\end{array}$ \\
\hline Vision & $\begin{array}{l}\text { Hyperopia, light strabismus, } \\
\text { state after grade } 2 \text { ROP, } \\
\text { necessity of wearing glasses }\end{array}$ & $\begin{array}{l}\text { Hyperopia, tendency } \\
\text { to strabismus, necessity } \\
\text { of wearing glasses }\end{array}$ & $\begin{array}{l}\text { Hyperopia, convergent strabismus, } \\
\text { state after grade } 3 \text { ROP and laser } \\
\text { therapy, necessity of wearing glasses }\end{array}$ \\
\hline Hearing & $\begin{array}{l}\text { Bilateral hearing } \\
\text { impairment }(40-50 \mathrm{~dB}), \text { ne- } \\
\text { cessity of using hearing aid }\end{array}$ & & \\
\hline Surgery & $\begin{array}{c}\text { Surgical closure of persistent } \\
\text { ductus arteriosus } \\
\text { at the } 3^{\text {rd }} \text { week of age }\end{array}$ & $\begin{array}{l}\text { Ventriculoperitoneal } \\
\text { shunting at } 12 \text { months } \\
\text { of age }\end{array}$ & $\begin{array}{l}\text { Laser therapy of both eyes (ROP) } \\
\text { at the } 3^{\text {rd }} \text { month of age }\end{array}$ \\
\hline Other & Weak muscular tonus & $\begin{array}{l}\text { Left-sided cerebral palsy, } \\
\text { weak muscular tonus }\end{array}$ & $\begin{array}{l}\text { Weak muscular tonus, } \\
\text { delayed psychomotor development }\end{array}$ \\
\hline
\end{tabular}

Łucja Bieleninik, Mariola Bidzan, Aneta Koszewska

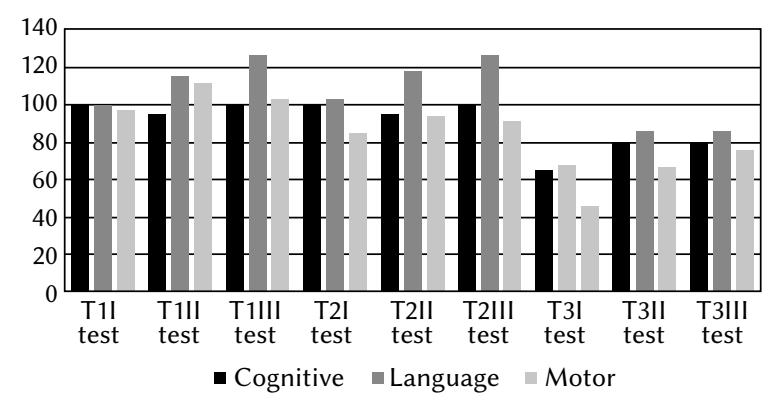

Figure 1. Psychomotor development of the siblings from triple pregnancy $(\mathrm{T} 1, \mathrm{~T} 2, \mathrm{~T} 3)$ assessed with BSID-III.

tation. Present medical and psychological status of examined siblings of triple pregnancy (T1, T2, T3) is summarized in Table 2.

\section{RESULTS}

Qualitative analysis of psychomotor development of examined siblings from triple pregnancy revealed differences in individual functioning; they are illustrated in Figure 1. The individual differences of triplets' developmental level pertained both to the particular developmental spheres and to the timing of development. We observed significant inter-sibling differences in the level of cognitive development. T1 and T2 represented an average level of development in that sphere at 24, 29, and 38 months of age, while T3 scored extremely low (65 points) on test I, and at the borderline of low average category ( 80 points) on tests II and III. Interesting relationships were observed with regards to language skills: both $\mathrm{T} 1$ and $\mathrm{T} 2$ scored average on test I, high average on test II, and superior on test III; T3 scored extremely low on test I, and low average on test II and III. Significant inter-sibling differences were observed at all ages with regards to motor skills; T1 developed the best, whereas the development of T3 was the worst on each testing. T1 scored average ( 97 points) on test I, high average (115 points) on test II, and again average (103 points) on test III. T2 scored low average on test I ( 85 points), and average (94 and 91 points, respectively) on test II and III. T3 scored extremely low (46 and 67 points, respectively), and had a borderline low score at 38 months.

Qualitative analysis of psychomotor development scores of $\mathrm{T} 1$ revealed that at 24 months of age (test I) this neonate was characterized by an average level of cognitive, language, and motor functioning. An improvement in motor and language skills was observed at 29 months of age (test II), as confirmed by high average scores in these spheres. Further improvement of language skills was documented at 38 months of age (test III), as suggested by the superior results of psychological examination. Longitudinal analysis of psychomotor development of T1 showed that the cognitive development of this neonate varied around an average level, while the competences in the remaining spheres were found to have improved in the course of consecutive tests, with the most pronounced improvement in language skills. The psychomotor development of T1 is summarized in Figure 2.

Qualitative analysis of psychomotor development of T2 at 24 months of age revealed average functioning with regards to cognitive and language skills, along with a low average motor functioning. At the age of 29 months (test II), T2 showed average development with regards to cognitive and motor skills, and scored high average in language skills. Consequently, this infant markedly improved language and motor competencies within a 5 -month period. Fur- 


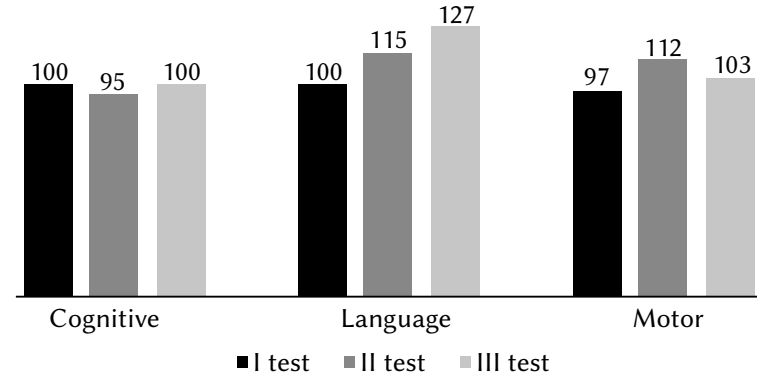

Figure 2. Psychomotor development of T1 assessed with BSID-III.

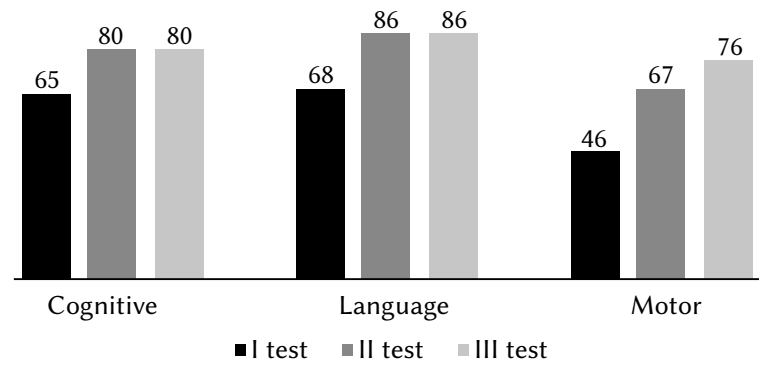

Figure 4. Psychomotor development of T3 assessed with BSID-III.

ther improvement of the language skills of the child was documented at 38 months of age (test III), from high average to a superior level. The psychomotor development of T2 is illustrated in Figure 3.

The characteristics of psychomotor development of T3 were markedly worse than the age-specific averages and the scores of the remaining siblings. At the age of 24 months (test I), T3 was characterized by an extremely low level of psychomotor development. Marked improvement of cognitive and language skills, to low average levels, was observed at another testing at 29 months of age. This improvement of cognitive and language functioning was confirmed by the results of psychological examination performed at 38 months of age (test III); moreover, an improvement in motor skills was observed, to a borderline low level. The psychomotor development of T3 is summarized in Figure 4.

Analysis of the language skills of siblings from triple pregnancy revealed inter-sibling differences in receptive communication (RC) and expressive communication (EC; Figure 5). At 24 months of age, T1 and T2 scored average with regards to RC and EC, while the scores of T3 were extremely low. Noticeably, all children improved their competencies in verbal and non-verbal aspects of communication, as confirmed by progressively higher scores determined at the age of 29 and 38 months. Of note, all three siblings achieved higher scores in expressive communication rather than in receptive communication. The characteristics of communication-related development were the worst in the case of T3. All examined children scored worst with regards to gross motor skills (GM; Figure 6).

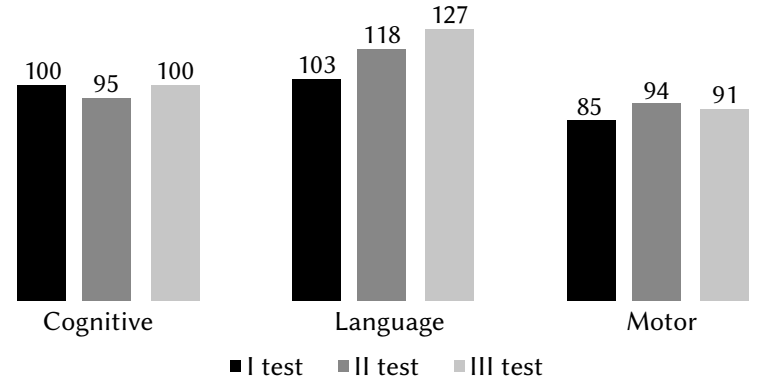

Figure 3. Psychomotor development of T2 assessed with BSID-III.

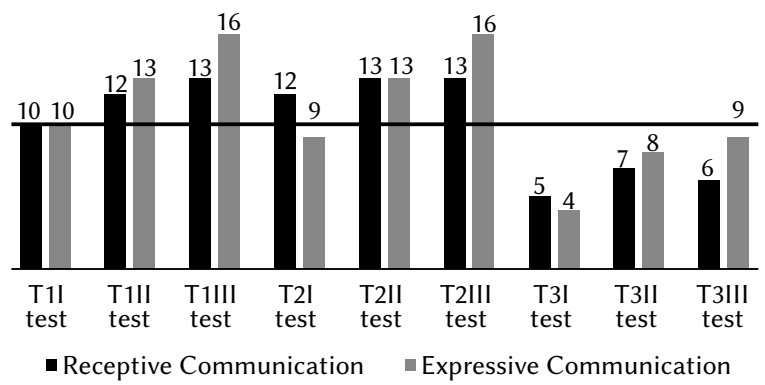

Figure 5. Subtest summary scores of the Bayley Scales of Infant and Toddler Development.

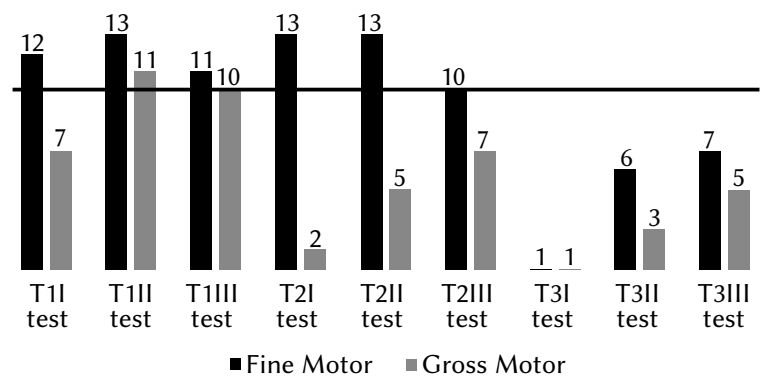

Figure 6. Subtest summary scores of the Bayley Scales of Infant and Toddler Development.

Only T1 scored average in this aspect; one should note extremely low GM scores of T2 and T3 observed in both tests. T1 and T2 possessed average scores with regards to fine motor skills (FM), while T3's score was extremely low, although with some improvement observed between consecutive measurements. T3 had extremely low scores of RC, EC, GM, and FM on test $\mathrm{I}$, and improved the skills in the $\mathrm{EC}$ and $\mathrm{RC}$ sphere to a borderline low level on test II (Figure 6).

\section{DISCUSSION}

The results of functional and developmental analysis of the siblings from triple pregnancies can be explained with regards to the effects of prematurity on the psychomotor development of children from multiple pregnancies and factors determining their development.
Triple pregnancy - psychomotor development 
Łucja Bieleninik, Mariola Bidzan, Aneta Koszewska
EFFECT OF PREMATURITY ON THE PSYCHOMOTOR DEVELOPMENT OF CHILDREN FROM MULTIPLE PREGNANCIES

The development of the analyzed siblings from triple pregnancies was impaired: discordant and characterized by a variable rate. This resulted from prematurity-related complications to a large extent. Previous studies confirmed that an increased survival rate of neonates with extremely low birth weight and gestational age is associated with a higher prevalence of handicapped individuals (Rijken et al., 2003). The siblings from triple pregnancies with gestational age of 29 weeks and birth weight $1240 \mathrm{~g}$ or lower represent a risk group of this condition. This finding was confirmed by the analysis of psychomotor development of children aged 24, 29, and 38 months. The analysis of BSID-III scores of children from triple pregnancy (T1, T2, T3) confirmed the influence of prematurity on early psychomotor development. Individual differences in the level of psychomotor development of siblings from triple pregnancy can be observed not only with regards to various spheres of development, but also in its timing. The results obtained in our siblings from the triple pregnancy $(\mathrm{T} 1, \mathrm{~T} 2, \mathrm{~T} 3)$ were confirmed in other studies.

Deficits of psychomotor development pertain both to premature children from singleton pregnancies and to those from twin and triple pregnancies. Consequently, these three groups of risk deserve special attention. Preterm children represent the risk group of developmental disorders, deficits, and discords (Kmita, 2003; Anderson \& Doyle, 2003) in the sphere of motor (Huber, Holditch-Davis, \& Brandon, 1993; Kmita, 2003; Anderson, de Luca, Hutchinson, Roberts, \& Doyle, 2010) and cognitive function (Huber et al., 1993; Magill-Evans \& Harrison, 2001; Kilbride, Thorstad, \& Daily, 2004; Woodward et al., 2006; Anderson et al., 2010; Chrzan-Dętkoś \& Bogdanowicz, 2010), linguistic development (Huber et al., 1993; Anderson et al., 2010), oculomotor coordination (Huber et al., 1993; Chlebna-Sokół, Ligenza, Świtalska, Wojtasik, \& Olszowiec, 2003; Hemgren \& Persson, 2006), visual analysis and synthesis (Kmita, 2003), and attention and perception (Hemgren \& Persson, 2006). Additionally, prematurity constitutes a risk factor of autism, attention deficit hyperactivity disorder (ADHD), and developmental coordination disorder (DCD). Problems with learning, dyslexia, and behavioral and emotional disorders have been noted. Many previous studies have analyzed the psychomotor development of preterm children from singleton pregnancies using the Bayley scale. For instance, a Taiwanese study used BSID-II to analyze 887 children with VLBW aged 6, 12, 18, and 24 months. In the study, $20.10 \%$ of the participants had average (90-109) values of MDI, $20.20 \%$ had low average scores (80-89), $17.20 \%$ low scores (70-79), and $8.50 \%$ extremely low scores (below 70 points) (Wang, Wang, \& Huang, 2008). Additionally, the development of children from twin pregnancies is impaired with regards to cognitive, language, emotional, and social spheres (Kornas-Biela, 2010; Leonard \& Denton, 2006). Also, children from triple pregnancies belong to the risk group of delayed cognitive and speech development. A Polish study by Chrzan-Dętkoś, Bogdanowicz, Baraniecka, and Karasiewicz (2008) revealed that at 1 and 2 years of age, siblings from triple pregnancy develop less congruently and more slowly than children from singleton pregnancies. A study by Bogdanowicz (1984) documented that preterm children from triple pregnancies are characterized by delayed psychomotor development at 5 months of age, but do not differ from preterm infants from singleton pregnancies in terms of psychomotor development at the age of 20 months. Feldman and Eidelman (2005) used BSID-II to analyze a group of 138 subjects from Israel, including 23 siblings from triple pregnancies, 23 pairs of twins, and 23 children from singleton pregnancies, aged 6,12 , and 24 months. Children from triple pregnancies had lower MDI as compared to twins and infants from singleton pregnancies. Akerman (1995, cited after: Chrzan-Dętkoś et al., 2008) reported similar findings. From the perspective of parents and specialists working with children, inconsistency in the functioning of siblings from triple pregnancies represents a particularly important aspect of this study; in the case of the analyzed siblings from triple pregnancy (T1, T2, T3), the inconsistency was observed with regards to cognitive, language, and motor spheres of development at 24, 29, and 38 months of age. Feldman and Eidelman (2005) emphasized that due to this functional inconsistency, siblings from triple pregnancies represent a group of particular risk. Moreover, the situation in which each of the triple infants requires individual developmental stimulation as well as different, health status-specific care additionally complicates the parental role.

\section{FACTORS DETERMINING DEVELOPMENT}

Despite common characteristics (parental, environmental, etc.), the examined siblings from triple pregnancy differed with regards to the rate and level of developing various abilities and skills. These differences resulted from the influence of child-specific factors constituting important determinants of development, such as individual characteristics of the child, or factors associated with the course of delivery and perinatal status of the neonate. We would like to highlight the results of previous studies confirming the role of these factors as determinants of development in children from multiple pregnancies.

The autcome from studies by Bidzan and Bieleninik (2013) have revealed a synergistic influence of 
biomedical predictors on the development of preterm infants with regards to cognitive functioning (28\% of variance), language skills ( $10 \%$ of variance), motor skills ( $18 \%$ of variance), fine motor skills ( $16 \%$ of variance), and gross motor skills (20\% of variance). Additional the Authors have observed an independent effect of birth weight, child's gender, and final Apgar score on the psychomotor development. Moreover, higher birth weight was associated with higher level of cognitive function and fine motor skills; male gender of a child was reflected by a higher level of cognitive function and language skills (including expressive communication), and higher final Apgar scores resulted in better gross motor skills (Bidzan \& Bieleninik, 2013). According to Bidzan and Bieleninik (2013) medical factors play a crucial role in the evaluation of psychomotor development in preterm infants.

The longitudinal twin study conducted by Gomółka-Walaszek and Walaszek (2008) revealed that postnatal development and psychophysical condition are determined by gestational age, birth weight, sequence of delivery, and time gap between delivering the first and the second twin from the pair. Also, intrauterine environment (location of the fetus, availability of nutrients, exposure to maternal antibodies), and characteristics of the perinatal period, including clinical status after birth, represent important factors that can cause differences in the functioning of children from multiple pregnancies. The research by Bidzan, Bieleninik, and Lipowska (2013) based on 52 preterm children (15 of which were born from a single pregnancy and 42 from a multiple pregnancy) has found statistically significant correlation between the exspressive comminication scores and gender, age at the time of testing, disability, gestational age, as well as birth weight in early childhood.

Birth weight constitutes one of the neonatal determinants of preterm child development during the neonatal and peri-kindergarten period; on the basis of their birth weight, neonates can be qualified to the relevant groups. Taking into account the birth weight of analyzed neonates from the triple pregnancy, T1, $\mathrm{T} 2$, and $\mathrm{T} 3$ can be qualified as follows:

- T1 with a birth weight of $980 \mathrm{~g}$ represented a neonate with an extremely low birth weight (ELBW; range of 750-1000 g);

- T2 with a birth weight of $1240 \mathrm{~g}$ represented a neonate with a very low birth weight (VLBW; 1000$1500 \mathrm{~g})$;

- T3 with a birth weight of $720 \mathrm{~g}$ was a neonate with an incredibly low birth weight (ILBW; below $750 \mathrm{~g}$ ).

These data not only emphasize the very low birth weight of the analyzed children $(<1240 \mathrm{~g})$, but also point to the differences in the birth weight of the siblings. It should be noted that the abovementioned values of birth weight of our neonates are consistent with published statistics. According to the literature,
$75 \%$ of neonates born between gestational week 25 and 32 have birth weight below $1500 \mathrm{~g}$, and in $20 \%$ of them the birth weight is lower than $1000 \mathrm{~g}$. Additionally, the low birth weight of the studied neonates (T1, T2, T3) could be the result of the type of pregnancy as a larger number of fetuses in multiple pregnancy was proved to be associated with lower birth weight of the neonates (Malinowski, 2009). Aside from gestational age, the neonatal birth weight is determined by maternal comorbidities, placental function, and maternal use of medications and other substances during pregnancy (Pająk et al., 2004); moreover, it is a polygenetic trait (Wolański, 2006).

Since birth weight constitutes an important prognostic factor of child functioning, including motor function (e.g. Chlebna-Sokół, Ligenza, Świtalska, Wojtasik, \& Olszowiec, 2003; Dezoete, MacArthur, Tuck, 2003) and IQ (Bhutta et al., 2002, cited after: Sondaar et al., 2008), many previous studies centered around the development of children with VLBW (Wang et al., 2008; Addison, Griffin, Moorman, Lake, \& O’Shea, 2009; Datar \& Jacknowitz, 2009) and ELBW (Hack et al., 2000; Kilbride et al., 2004; Laptook, O’Shea, Shankaran, \& Bhaskar, 2005; Anderson et al., 2010; Gidley Larson et al., 2011). Approximately $50 \%$ of children with extremely low birth weight are characterized by at least one deficit in cognitive and motor spheres (Kmita, 2003). Datar and Jacknowitz (2009) analyzed the influence of birth weight on the development of monozygotic and dizygotic twins at 9 months and 2 years of age; they observed that both VLBW $(<1500 \mathrm{~g})$ and moderately low birth weight (MLBW) (1500-2499 g) have a significant negative impact on the development of cognitive and motor function and growth during the first two years of life.

Gestational age (GA) also represents a risk factor of neurological disorders and delayed development (Hack et al., 2000; Stoelhorst et al., 2003; Lando, Klamer, Jonsbo, Weiss, \& Greisen, 2005; Wood et al., 2005; Kiechl-Kohlendorfer, Ralser, Pupp Peglow, Reiter, \& Trawöger, 2009; Maguire et al., 2009). According to Walas (2008), it is gestational age rather than birth weight that determines the functioning of the child. Consequently, it should be emphasized that children from our group were born at the $29^{\text {th }}$ week of gestation. According to the literature, the average gestational age is 35 weeks in twins, 32 weeks in children from triple pregnancies, and 29 weeks in children from quadruple pregnancies; in contrast, the average gestational age of neonates from singleton pregnancies is around 39 weeks (Alehander et al., 1998, cited after: Malinowski, 2009; Malinowski \& Bręborowicz, 2010). The study by Addison et al. (2009), using BSID-II, revealed that the birth weight corresponding to VLBW is associated with poor functioning ( $<70$ points) in motor and cognitive spheres. This author documented a significant relationship between gestational age ranging from 23 to 29 weeks and 406-1439 g birth weight, and
Triple pregnancy - psychomotor development 
Łucja Bieleninik, Mariola Bidzan, Aneta Koszewska values of Mental Developmental Index (MDI) below 70 points.

Also, Apgar score is an important determinant of the psychomotor development of the neonate (van Kessel-Feddema et al., 2007), and the score determined at the $5^{\text {th }}$ minute of life can be used as a prognostic factor of delayed development (Bień, Bałanda-Bałyga, \& Skurzak, 2009). Noticeably, all our siblings had a 7-point Apgar score.

Of note, all anthropometric parameters of preterm children are lower than in full-term neonates (Bień et al. 2009). Body length is associated with birth weight. T2 was the longest at birth $(43 \mathrm{~cm})$, which corresponded to the highest birth weight of all analyzed neonates. The lengths of remaining neonates, T1 and T2, were $38 \mathrm{~cm}$ and $36 \mathrm{~cm}$, respectively. Head circumference should also be considered amongst neonatal anthropometric characteristics; it can represent a prognostic factor of impaired neurological development (Rijken, Wit, le Cessie, \& Veen, 2007). In this study, the head circumferences of T1 and T2 were 29 cm each, while T3 had a head circumference of $25 \mathrm{~cm}$.

Other factors that can modulate the development of the child include post-birth medical complications (Morris, Smith, Swank, Denson, \& Landry, 2002; Stoelhorst et al., 2003; Wood et al., 2005; van Kessel-Feddema et al., 2007). Our triple neonates were born with signs of hypoxia requiring administration of oxygen, artificial ventilation, and intubation. According to the literature, children who experienced hypoxia show impaired psychomotor development at older age, namely around the $7^{\text {th }}$ and $8^{\text {th }}$ years of age, when the development of the brain is already completed (Bałanda-Bałdyga, Skurzak, Iwanowicz-Palus, Bień, \& Kiełbratowska, 2009). The disorders of psychomotor development include spastic hemiparesis of upper limbs, and impaired mental development (Kornacka, 2000). Other determinants of delayed development of preterm infants include clinical conditions complicating preterm birth, such as bronchopulmonary dysplasia (BPD) (Stoelhorst et al., 2003; van Kessel-Feddema et al., 2007); this occurred in one of the analyzed children (T3). Additionally, it should be noted that the studied siblings from triple pregnancy suffered from RDS, ROP, and postnatal infection. Overall, preterm children, especially those with neurological/intracranial injuries acquired during pregnancy, belong to the risk group of neurodevelopmental disorders (Vollmer et al., 2003; Wood et al., 2005). Two of our children (T1 and T3) had intraventricular bleeding; additionally, persistent ductus arteriosus was documented in $\mathrm{T} 1$, along with leukomalacia in T2. Noticeably, according to the literature, leukomalacia, bronchopulmonary dysplasia, and arterial hypertension of preterm neonates constitute the main risk factors of neurological complications at birth (Martens et al., 2003).
A study of 167 preterm infants from Israel and New Zealand (gestational age of 30 weeks or less) revealed that abnormal MRI at birth represents a significant predictor of neurological capacity of children at 2 years of age. Moderate or severe abnormalities in the white matter of the brain were observed in $21 \%$ of children participating in this study; they were reflected by delayed development with regards to cognitive and motor function, as well as by neurosensory disorders and cerebral palsy (10\%). In the case of $49 \%$ of the children, the abnormalities of the gray matter corresponded to delayed cognitive and motor development, as well as cerebral palsy (Woodward et al., 2006). Of note, one of our neonates (T2) was diagnosed with cerebral palsy. The incidence of cerebral palsy in children from multiple pregnancies is higher (Johnson et al., 2002, cited after: Kornas-Biela, 2010) and can be even 12 times more frequent as in children from singleton pregnancies (Kornacka, 2003b). Depending on the type of pregnancy, the proportion of neonates with cerebral palsy has been reported as follows: 2-2.5 per 1000 children from singleton pregnancy, 13 per 1000 children from twin pregnancy, and 17-71 per 1000 children from triple pregnancy (Porta, 2001; Czochańska, 1999, cited after: Kornacka, 2003b). Also, race and gender are prognostic factors of motor disorders with higher risk associated with Caucasian race and male gender as compared to Black race and female gender (Morris et al., 2002; Stoelhorst et al., 2003; Wood et al., 2005; van Kessel-Feddema et al., 2007). It was suggested that this relationship results from the fact that female neonates are more mature at birth (Wolański, 2006). The study conducted by Wood et al. (2005) in a group of 308 neonates from the UK and Ireland, born at gestational week 25 and earlier, revealed that male gender is a frequent risk factor of poor functional motor scores, motor impairment, and cerebral palsy at 30 months of corrected age. Cerebral palsy was diagnosed in $19 \%$ of the studied population $(n=54)$, and the risk of developing this condition by male infants was twice as high as in females. Moreover, $10 \%$ of participating infants $(n=28)$ showed severe motor impairment or deficit in one or two functions (standing, walking, sitting, using hands, gait and movement control) (Wood et al., 2005). Furthermore, the risk of developmental disorders can be increased in the case of gender consistency of children from multiple pregnancies (Kornacka, 2003b).

The mode of delivery is determined by gestational age and presentation of the fetus. It should be noted that the mode of pregnancy termination affects the somatic status of both the pregnant woman and the neonate. Multiple pregnancies are more frequently resolved by a cesarean section. This was the case of our children; their presentation at birth was as follows: T1 - head presentation, T2 - transverse presentation, T3 - breech presentation. According 
to Chen, Wang, and Fang (2005) and Barber, Sikes, and Norton (2007), terminating pregnancy by means of a cesarean section is reflected by a reduced morbidity rate in preterm neonates with birth weight below 1500 g. Sobantka et al. (2007) observed that termination of preterm pregnancy by means of cesarean section improves the chances of neonatal survival. However, other authors did not document a significant relationship between the mode of delivery and neonatal morbidity (Malloy, Onstad, \& Wright, 1991; Paul, Sciscione, Leef, \& Strefano, 2002) and survival (Maciejewski, Kowalska, Rutkowska, \& Szamotulska, 2008).

Parental factors determining the development of the child include educational level, socioeconomic status, the occurrence of maternal depression, maternal age at preterm delivery, and ethnicity (Stoelhorst et al., 2003; Wang et al., 2008; Fuertes, Faria, \& Soares, 2009; Patrianakos-Hoobler, Msall, Marks, Huo, \& Schreiber, 2009; Anderson et al., 2010). However, these factors exert complex negative effects when acting together rather than independently. According to some authors, the developmental impact of social and environmental factors can be stronger than the influence of perinatal complications, particularly with regards to the linguistic sphere (Magill-Evans \& Harrison, 2001); however, verification of this theory was not an objective our study.

Also, various forms of interventions should be enumerated amongst factors influencing child development. Our siblings from triple pregnancy (T1, T2, T3) took part in four two-week rehabilitation cycles (September 2010, November 2010, May 2011, September 2011), and were included in the Program of Early Developmental Support. Vanderveen, Bassler, Robertson, and Kirpalani (2009) published the results of a meta-analysis of studies dealing with cognitive and motor development of a group of 2198 12-montholds. They revealed that children subjected to various forms of intervention, including parental education, stimulation of development, home visits, and individualized care, showed better cognitive $(n=2198)$ and motor function $(n=1319)$. However, the authors emphasized that the positive clinical effects of these forms of support can be observed no earlier than after 36 months of age.

Explaining the differences between the results of tests I, II, and III, conducted amongst the siblings from triple pregnancy, we would like to emphasize that each of our infants experienced a perinatal injury of cerebral structures. This was reflected by the impairment of brain-derived processes and delayed development; this was confirmed on test I, during which each of three children showed abnormalities in at least one developmental sphere. However, on tests II and III, each child scored better as compared to previous testing. Although this improvement unambiguously resulted from a natural developmental process, T1 and T2 scored average, high average, or even superior in most analyzed spheres. This phenomenon can be interpreted in terms of parcellation and heterochrony processes, as well as in terms of brain plasticity, pertaining to the ongoing process of developmental and injury-related changes (Pąchalska, 2007; Borkowska \& Domańska, 2011).

\section{CONCLUSIONS}

1. Individual psychomotor development of children from triple pregnancy is different with regards to various spheres, and has different rates and dynamics throughout consecutive years.

2. Psychomotor development of children from triple pregnancies is determined by gender and postnatal clinical parameters, i.e. birth weight, head circumference, postnatal morbidity, and prematurity-related conditions.

3. The risk of cerebral palsy can be associated with prematurity, multiple pregnancy, and gender.

\section{References}

Addison, K., Griffin, M., Moorman, J., Lake, D., \& O'Shea, T. (2009). Heart rate characteristics and neurodevelopmental outcome in very low birth weight infants. Journal of Perinatology, 29, 750756.

Anderson, P. J., de Luca, C. R., Hutchinson, E., Roberts, G., Doyle, L. W., and the Victorian Infant Collaborative Group. (2010). Underestimation of Developmental Delay by the New Bayley-III Scale. Archives of Pediatrics \& Adolescent Medicine, 164, 352-356.

Anderson, P., \& Doyle, L. W. (2003). Neurobehavioral outcomes of school-age children born extremely low birth weight or very preterm in the 1990s. The Journal of the American Medical Association, 289, 3264-3272.

Bałanda-Bałdyga, A., Skurzak, A., Iwanowicz-Palus, G. J., Bień, A. M., \& Kiełbratowska, B. (2009). Opieka nad wcześniakiem z wybranymi problemami klinicznymi [Caring for a prematurely born child with selected clinical problems]. A. B. PilewskaKozak (ed.), Opieka nad wcześniakiem [Caring for a prematurely born child] (pp. 141-163). Warszawa: PZWL.

Barber, C. A., Sikes, N. C., Norton, J. D., Lowery, C. L., \& Kaiser, J. R. (2007). Effects of mode of delivery on mortality and severe brain injury in extremely low birth weight infants in Arkansas. The Journal of the Arkansas Medical Society, 104, 63-66.

Bayley, N. (2006). Scales of Infant and Toddler Development, Third Edition, Technical Manual, NCS Pearson.
Triple pregnancy - psychomotor development 
Łucja Bieleninik, Mariola Bidzan, Aneta Koszewska
Bieleninik, Ł. (2012). Dzieci przedwcześnie urodzone w percepcji matek [Mothers' perception of prematurely born children]. Gdańsk: Harmonia Universalis.

Bieleninik, Ł., \& Gold, C. (2014). Early intervention for premature infants in neonatal intensive care unit. Acta Neuropsychologica, 12, 185-203.

Bidzan, M., \& Bieleninik, Ł. (2013). Psychomotor development of preterm babies in the context of biomedical predictors in a Polish sample. Health Psychology Report, 1, 18-33. DOI: 10.5114/ hpr.2013.40466

Bidzan, M., Bieleninik, Ł., \& Lipowska, M. (2013). The development of speech in early childhood in children from twin pregnancies with twin-twin transfusion syndrome (TTTS). Polish Psychological Bulletin, 44, 9-20. DOI: 10.2478/ppb-2013-0002

Bień, A., Bałanda-Bałyga, A., \& Skurzak A. (2009). Zasady postępowania z noworodkiem urodzonym przedwcześnie podczas porodu i bezpośrednio po urodzeniu [Clinical practice guidelines with regards to premature newborns during labour and directly after birth]. A. B. Pilewska-Kozak (ed.), Opieka nad wcześniakiem [Caring for a prematurely born child] (pp. 61-69). Warszawa: PZWL.

Bogdanowicz, M. (1984). Psychomotor development of children from multiple pregnancies. A psychological evaluation. Acta Geneticae Medicae et Gemmellogoliae, 22, 135-138.

Borkowska, A., \& Domańska, Ł. (2011). Plastyczność mózgu [Plasticity of the brain]. In: Ł. Domańska, \& A. Borkowska (eds.), Podstawy neuropsychologii klinicznej [The basics of clinical neuropsychology] (pp. 113-125). Lublin: UMCS.

Bracewell, M., \& Marlow, N. (2002). Pattern of Motor Disability in Very Preterm Children. Mental Retardation and Developmental Disabilites Rerearch Reviews, 8, 241-248.

Chen, P. C., Wang P. W., \& Fang L. J. (2005). Prognostic predictors of neurodevelopmental outcome or mortality in very-low-brith-weight infants. Acta Paediatrica Taiwanica, 46, 196-200.

Chlebna-Sokół, D., Ligenza, I., Świtalska, J., Wojtasik, K., \& Olszowiec, M. (2003). Ocena rozwoju intelektualno-poznawczego dzieci w wieku 4-7 lat urodzonych przedwcześnie. Część I. Analiza badań psychologicznych [Assessment of the intellectual and cognitive development of prematurely born children aged between 4 and 7]. Psychiatria i Psychologia Kliniczna, 1, 34-42.

Chrzan-Dętkoś, M., \& Bogdanowicz, M. (2010). Rozwój psychoruchowy bliźniąt urodzonych przedwcześnie [Psychomotor development of prematurely born twins]. In: T. Rostowska, \& B. Pastwa-Wojciechowska (eds.), Rozwój bliźniąt w ciagu życia. Aspekty Biopsychologiczne [Development of twins throughout their lifetime. Biopsychological aspects] (pp. 193-203). Kraków: Impuls.
Chrzan-Dętkoś, M., Bogdanowicz, M., Baraniecka, M., \& Karasiewicz K. (2008). The psychomotor development of preterm children born from multiple pregnancies. Acta Neuropsychologica, 2, 122-139.

Chrzan-Dętkoś, M., Pawlicka, P., \& Bogdanowicz, M. (in print). The effects of kangaroo mother care in a sample of preterm, preschool aged children. Health Psychology Report, 2. DOI: 10.5114/ hpr.2014.44423

Datar, A., \& Jacknowitz, A. (2009). Birt Weith Effects on Chilren's Mental, Motor, and Physical Development: Evisdence from Twins Data. Maternal and Child Health Journal, 13, 780-794.

Dezoete, J. A., MacArthur, B. A., \& Tuck, B. (2003). Prediction of Bayley and Stanford-Binet scores with a group of very low birthweight children. Child: Care, Health \& Development, 29, 367-372.

Feldman, R., \& Eidelman, A. I. (2005). Does a Triplet Birth Pose and Special Risk for Infant Development? Assessing Cognitive Development in Relation to Intrauterine Growth and Mother - Infant Interaction Across the First 2 Year. Pediatrics, 155, 443-452.

Fuertes, M., Faria, A., \& Soares, H. (2009). Developmental and evolutionary assumption in a study about the impact of premature birth and low income on mother-infant interaction. Acta Ethologica, 12, 1-11.

Gadzinowski, J., \& Gulczyńska, E. (2003). Ciąża wielopłodowa - uwarunkowania ekonomiczne [Multiple pregnancy - economical determinants]. In: G. Bręborowicz, W. Malinowski, E. Ronin-Walknowska (eds.), Ciaża wielopłodowa [Multiple pregnancy] (pp. 27-32). Poznań: Ośrodek Wydawnictw Naukowych.

Gidley Larson, J. C., Baron, I. S., Erickson, K., Ahronivich, M. D., Baker, R., \& Litman, F. R. (2011). Neuromotor Outcomes at School Age After Extremely Low Birth Weight: Early Detection of Subtle Sings. Neuropsychology, 23, 66-73.

Gomółka-Walaszek, I., \& Walaszek, A. (2008). Interakcje opiekowania się $\mathrm{w}$ rozwoju psychoruchowym bliźniąt [Care interactions in psychomotor development of twins]. Perinatologia, Neonatologia i Ginekologia, 1, 294-301.

Hack, M., Wilson-Costello, D., Friedman, H., Taylor, G. H., Schluchter, M., \& Fanaroff, A. A. (2000). Neurodevelopment and Predicators of Outcomes of Children With Birth Weights of Less Than $1000 \mathrm{~g}$. Archives of Pediatrics and Adolescent Medicine, 154, 725-731.

Hemgren, E., \& Persson, K. (2006). Associations of Motor co-ordination and attention with motor-perceptual development in 3-year-old preterm and full-term children who needed neonatal intensive care. Child: Care, Health \& Development, 33, 11-21. 
Huber, C., Holditch-Davis, D., \& Brandon, D. (1993). High-Risk Preterm Infants at 3 Years of Age: Parental Response to the Presence of Developmental Problems. Children's Health Care, 22, 107-124.

Kania, J. (2008). Diagnostyka zaburzeń neurorozwojowych noworodków i niemowląt [Diagnostics of neurodevelopmental disorders of newborns and infants]. In: I. Pirogowicz, \& A. Steciwko (eds.), Dziecko i jego środowisko. Noworodek przedwcześnie urodzony - trudności i satysfakcje [The child and its environment. Prematurely born newborn - difficulties and gratifications] (pp. 89-96). Wrocław: Conlinuo.

Kempiak, J. (2003). Ciąża wielopłodowa - umieralność okołoporodowa płodów i noworodków [Multiple pregnancy - perinatal mortality of foetuses and newborns]. In: G. H. Bręborowicz, W. Malinowski, \& E. Ronin-Walknowska (eds.), Ciąża wielopłodowa [Multiple pregnancy] (pp. 373-379). Poznań: OWN.

Kiechl-Kohlendorfer, U., Ralser, E., Pupp Peglow, U., Reiter, G., \& Trawöger, R. (2009). Adverse neurodevelopmental outcome in preterm infants: risk factor profiles for different gestational ages. Acta Pediatrica, 98, 792-796.

Kilbride, H. W., Thorstad K., \& Daily D. K. (2004). Preschool Outcome of Less Than 801-Gram Preterm Infants Compared With Full-Term Siblings. Pediatrics, 113, 742-747.

Kmita, G. (2003). Rozwój psychiczny dzieci urodzonych przedwcześnie [Psychological development of prematurely born children]. In: M. K. Kornacka (ed.), Noworodek przedwcześnie urodzony - pierwsze lata życia [Prematurely born newborn - first years of life] (pp. 55-67). Warszawa: PZWL.

Kornacka, M. K. (2000). Zaburzenia neurologiczne [Neurological disorders]. In: J. Szczapa (ed.), Neonotalogia [Neonatology]. Warszawa: PWN.

Kornacka, M. K. (2003a). Opieka specjalistyczna nad dzieckiem urodzonym przedwcześnie [Specialist care for prematurely born child]. In: M. Kornacka (ed.), Noworodek przedwcześnie urodzony - pierwsze lata życia [Prematurely born newborn - first years of life] (pp. 7-20). Warszawa: PZWL.

Kornacka, M. K. (2003b). Rozwój dzieci z ciąż wielopłodowych [Development of children of multiple pregnancies]. In: G. H. Bręborowicz, W. Malinowski, E. Ronin-Walknowska (eds.), Ciqzża wieloptodowa [Multiple pregnancy] (pp. 363-371). Poznań: OWN.

Kornacka, M., \& Sonczyk, A. (2008). Noworodek z ciąży wielopłodowej wymagający intensywnej terapii - problem narastający czy malejący? [Newborns from multiple pregnancies requiring intensive care - an increasing or decreasing problem?]. Perinatologia, Neonatologia i Ginekologia, 1, 260-264.

Kornas-Biela, D. (2010). Bliźnięta i wieloraczki w pre- i perinatalnym okresie rozwoju [Twins and multiples in the pre- and perinatal period of development]. In: T. Rostowska, \& B. PastwaWojciechowska (eds.), Rozwój bliźniąt w ciagu życia. Aspekty biopsychologiczne [Development of twins throughout their lifetime. Biopsychological aspects] (pp. 65-99). Kraków: Impuls.

Kostuch, M. (2009). Ocena stopnia dojrzałości i stanu noworodka urodzonego przedwcześnie [Assessment of maturity levels and health of a prematurely born newborn]. A. B. Pilewska-Kozak (ed.), Opieka nad wcześniakiem [Caring for a prematurely born child] (pp. 70-80). Warszawa: PZWL.

Lando, A., Klamer, A., Jonsbo, F., Weiss, J., \& Greisen, G. (2005). Developmental delay at 12 months in children born extremely preterm. Acta Paediatrica, 94, 1604-1607.

Laptook, A. R., O’Shea, M., Shankaran, S., \& Bhaskar, B. (2005). Adverse Neurodevelopmental Outcomes Among Extremely Low Birth Infants With a Normal Head Ultrasound: Prevalence and Antecedents. Pediatrics, 115, 673-680.

Leonard, L. G., \& Denton J. (2006). Preparation for parenting multiple birth children. Early Human Development, 82, 371-378.

Maciejewski, T., Kowalska, B., Rutkowska, M., \& Szamotulska, K. (2008). Ocena ryzyka nieprawidłowego neurologicznego rozwoju dzieci urodzonych przedwcześnie w zależności od drogi porodu [Assessment of risk of abnormal neurological development of prematurely born children, depending on the way of delivery]. Perinatologia, Neonatologia i Ginekologia, 1, 98-102.

Magill-Evans, J., \& Harrison, M. J. (2001). Parent-child interactions, parenting stress, and developmental outcomes at 4 years. Children's Health Care, 30, 135-150.

Maguire, C. M., Walther, F. J., van Zwieten, P. H. T., Le Cessie, S., Wit, J. M., \& Veen, S. and behalf of the Leiden Developmental Care Project (2009). Follow-up Outcomes at 1 and 2 Years of Infants Born Less Than 32 Weeks After Newborn Induvidualized Developmental Care and Assessment Program. Pediatrics, 123, 1081-1087.

Malinowski, W. (2009). Epidemia ciąż wielopłodowych. Nowy problem w położnictwie [The epidemic of multiple pregnancies. A new issue of obsterics]. Perinatologia, Neonatologia i Ginekologia, 2, 90-93.

Malinowski, W., \& Bręborowicz, G. H. (2010). Ciąża wielopłodowa [Multiple pregnancy]. In: G. H. Bręborowicz (ed.), Ciąża wysokiego ryzyka [High-risk pregnancy] (pp. 259-294). Poznań: MMX.

Malloy, M. N., Onstad, L., \& Wright, E. (1991). The effect of cesarean delivery on birth outcome in very low birth weight infants. Obstetrics \& Gynecology, 77, 498-503.

Martens, S. E., Rijken, M., Stoelhorst, G. M., van Zwieten, P. H., Zwinderman, A. H., Wit, J. M., Hadders-Algra, M., \& Veen, S. (2003). Is hypotension
Triple pregnancy - psychomotor development 
Łucja Bieleninik, Mariola Bidzan, Aneta Koszewska a major risk factor for neurological morbidity at term age in very preterm infants? Early Human Development, 75, 79-89.

Morris, B. H., Smith, K. S., Swank, P. R., Denson, S. E., \& Landry, S. H. (2002). Patterns of Physical an Neurologic Development in Preterm Children. Journal of Perinatology, 22, 31-36.

Nowakowska, D., \& Wilczyński, J. (2003). Poród przedwczesny w ciąży wielopłodowej [Premature labour in multiple pregnancy]. In: G. H. Bręborowicz, W. Malinowski, E. Ronin-Walknowska (eds.), Ciąża wieloptodowa [Multiple pregnancy] (pp. 157-171). Poznań: Ośrodek Wydawnictw Naukowych.

Pąchalska, M., Lipowska, M., \&Łukaszewska, B.(2007). Towards a process neuropsychology: Microgenetic theory and brain science. Acta Neuropsychologica, 5, 228-245.

Pająk, J., Halbersztadt, A., Bal, J., Kozak, J., Stefaniak, M., Czyżewska, M., \& Gabryś, M. S. (2004). Wykonanie zabiegu cesarskiego nie poprawia stanu urodzeniowego noworodków w przypadku przedwczesnego odpłynięcia płynu owodniowego pomiędzy 26 a 34 tygodniem ciąży [Performance of caesarean section does not improve the status of the neonate in case of premature rupture of membranes between 26th and $34^{\text {th }}$ week of pregnancy]. Ginekologia Polska. Suplement [Polish gynaecology. Supplement], 310-314.

Patrianakos-Hoobler, A. I., Msall, M. E., Marks, J. D., Huo, D., \& Schreiber, M. D. (2009). Risk Factors Affecting School Readiness in Premature Infants With Respiratory Distress Syndrome. Pediatrics, 124, 258-267.

Paul, D. A., Sciscione, A., Leef, K. H., \& Strefano, J. L. (2002). Caesarean delivery and outcome in very low birthweitht infants. Australian and New Zealand Journal of Obstetrics and Gynaecology, 42, 41-45.

Pawelczyk, L., \& Derwich, K. (2003). Ciąża wielopłodowa po technikach wspomaganego rozrodu [Multiple pregnancy after the use of assisted reproductive technologies]. In: G. H. Bręborowicz, W. Malinowski, \& E. Ronin-Walknowska (eds.), Ciazża wielopłodowa [Multiple pregnancy] (pp. 5056). Poznań: Ośrodek Wydawnictw Naukowych.

Pąchalska, M. (2007). Neuropsychologia kliniczna. Urazy mózgu [Clinical neuropsychology. Brain injuries]. Warszawa: PWN.

Pietrzycka, D., \& Gadzinowski, J. (2007). Opieka perinatalna w krajach Europy Środkowej i Wschodniej [Perinatal care in countries of Central and Eastern Europe]. Kliniczna Perinatologia i Ginekologia, 43, 7-14.

Rijken, M., Stoelhorst, G., Martens, E., van Zwieten, P. H., Brand, R., Wit, J. M., \& Veen S. (2003). Mortality and neurologic, mental and psychomotor development at 2 years in infants born less than 27 weeks' gestation: the Leiden Follow-Up Project on Prematurity. Pediatrics, 112, 351-358.
Rijken, M., Wit, J. M., le Cessie, S., \& Veen, S. (2007). The effect of perinatal risk factors on growth in very preterm infants at 2 years of age: the Leiden Follow-up Project on Prematurity. Early Human Development, 83, 527-534.

Sobantka, S., Baum, M., Jacaszek, M., Biesiada, L., Pietrzak, Z., \& Krasomski, G. (2007). Przebieg ciąży i porodu w ciążach między 23. a 30. tygodniem ciąży. Wyniki położnicze i noworodkowe. Analiza przeżyciowa [The course of pregnancy and labour in pregnancies between the $23^{\text {rd }}$ and $30^{\text {th }}$ week of the pregnancy. Obstetric and newborn results. Survival analysis]. Kliniczna Perinatologia i Ginekologia, 43, 65-67.

Sondaar, M., van Kessel, B. J., de Kleine, M. J., Briët, J. M., den Ouden, A. L., \& van Baar A. (2008). Do Pediatricians Recognize Cognitive Developmental Problems in Preterm Children at Age 5 Years? The Journal of Developmental and Physical Disabilities, 20, 21-29.

Stoelhorst, G. M., Rijken, M., Martens, S. E., van Zwieten, P. H., Feenstra, J., Zwinderman, A. H., Wit, J. M., $\&$ Veen, S. (2003). Developmental outcome at 18 and 24 months of age in very preterm children: a cohort study from 1996 to 1997. Early Human Development, 72, 83-95.

Stoińska, B., \& Montgomery, A. (2003). Model i rola poradni wczesnej oceny rozwoju dziecka [Model and role of clinics of early assessment of child development]. In: M. K. Kornacka (ed.), Noworodek przedwcześnie urodzony - pierwsze lata życia [Prematurely born newborn - first years of life] (pp. 21-32). Warszawa: PZWL.

Szymankiewicz, M. (2010). Zachorowalność i umieralność noworodków $\mathrm{z}$ ciąż wielopłodowych [Morbidity and mortality of newborns from multiple pregnancies]. Perinatologia, Neonatologia i Ginekologia, 3, 245-248.

van Kessel-Feddema, B., Sondaar, M., de Kleine, M., Verhaak, C., \& van Baar, A. (2007). Concordance between school outcomes and developmental follow-up results of very preterm and/or low birth weight children at the age of 5 years. European Journal of Pediatrics, 166, 693-699.

Vanderveen, J., Bassler, D., Robertson, C., \& Kirpalani, H. (2009). Early intervention involving parents to improve neurodevelopmental outcomes of premature infants: a meta-analysis. Journal of Perinatology, 29, 343-351.

Vollmer, B., Roth, S., Baudin, J., Stewart, A. L., Neville, B. G., \& Wyatt, J. S. (2003). Predictors of LonTerm Outcome in Very Preterm Infants: Gestional Age Versus Neonatal Cranial Ultrasound. Pediatrics, 112, 1108-1114.

Walas, W. (2008). Bardzo trudne początki, czyli wcześniak na oddziale intensywnej terapii [A very difficult beginning - a prematurely born newborn in intensive care]. In: I. Pirogowicz, A. Steciwko (eds.), Dziecko i jego środowisko. Noworodek przed- 
wcześnie urodzony - trudności i satysfakcje [The child and its environment. Prematurely born newborns - difficulties and gratifications] (pp. 7-21). Wrocław: Conlinuo.

Wang, L. W., Wang, S. T., \& Huang, C. C. (2008). Preterm infants of educated mothers have better outcome. Acta Pediatrica, 97, 568-573.

Wolański, N. (2006). Rozwój biologiczny człowie$k a$ [Human biological development]. Warszawa: PWN.

Wood, N. S., Costeloe, K., Gibson, A. T., Hennessy, E. M., Marlow, N., \& Wilkinson, A. R., EPICure Study Group. (2005). the EPICure study: associations and antecedents of neurological and developmental disability at 30 months of age following extremely preterm birth. Archives of Disease in Childhood - Fetal and Neonatal Edition, 90, 134140.

Woodward, L. J., Anderson, P. J., Austin, N. C., Howard, K., \& Inder, T. E. (2006). Neonatal MRI to Predict Neurodevelopmental Outcomes in Preterm Infants. The New England Journal of Medicine, 355, 685-694. 